\title{
Community Empowerment in Batu Tourism City Through Local Wisdom- Based Creative Economics
}

\author{
Ana Sopanah ${ }^{1}$, Syamsul Bahri ${ }^{2}$, Mohammad Ghozali $^{3}$ \\ Department of Accounting, University of Widyagama, Malang ${ }^{1,2}$, Department of Syari'ah \\ Economic Law, University of Darussalam Gontor, Ponorogo ${ }^{3}$ \\ \{anasopanah@widyagama.ac.id\}
}

\begin{abstract}
Tourism is a variety of tourist activities and is supported by various facilities and services provided by the community, businesses, central government, and the local government. Currently, many tourist places emerge with their own unique appeals. One of them is Batu Tourism City, which is always crowded with tourists from various cities and regions in Indonesia. Batu is indeed known as one of the leading tourist cities in Indonesia because of its potential for extraordinary natural beauty. Of the many tourist objects offered by the city, there are also thematic tourist attractions that empower the surrounding community by elevating cultural characteristics and preserving their local wisdom. This form of local wisdom provides opportunities for creativity in the community which in turn creates creative industries. This kind of creative economy is growing rapidly in Indonesia, including in Batu. In addition, the emergence of various thematic tours encourages the growth of creative economy in society. The purpose of this research is to formulate a community empowerment strategy for creative economy actors based on local wisdom (i.e. batik fabric) in Batu. The research used the AHP and ANP analysis. The results show that batik can be used as a promising business opportunity as well as a platform for cultural learning and preservation by creating batik patterns based on local wisdom. The growth of a society's creative economy will give a profound impact on people's lives, especially in terms of their economy.
\end{abstract}

Keywords: Creative Economy, Community Empowerment Strategies, Batik, Batu Tourist City

\section{Introduction}

According to Indonesian Act No. 10/2009, tourism is a variety of tourism activities and is supported by various facilities and services provided by the community, businesses, the central government and the local government. Currently, many tourist places emerge with their own unique appeals. One of them is Batu Tourism City, which is always crowded with tourists from various cities and regions in Indonesia. Batu is indeed known as one of the leading tourist cities in Indonesia because of its potential for extraordinary natural beauty. The admiration of the Dutch for Batu's natural beauty made them compared the city with a country in Europe, namely Switzerland, and hence the nickname of De Kleine Zwitserland or "Little 
Switzerland in Java Island." Batu is also a part of a regional area known as Malang Raya (Malang Greater Area).

Many tourist attractions are offered in this city, from the natural ones to the man-made ones. The number of visitors to this city is one of the largest, after Bali and Yogyakarta. Batu tourist attractions are very diverse in category, from historical, retail, educational, to natural areas. In the Songgoriti natural tourist destination, there is the Songgoriti Temple, a relic of the Medang Kingdom, a Ganesha statue from the Singhasari Kingdom, and a resting place built since the Dutch era. The family tourist destinations in Batu include Jatim Park 1, Jatim Park 2, Jatim Park 3, Predator Fun Park, and others.

Of the many tourist objects offered by the city, there are also thematic tourist attractions that empower the surrounding community by elevating cultural characteristics and preserving their local wisdom. Local wisdom is essentially an activity that protects and preserves nature and the environment. Therefore, it is important to study and preserve local wisdom that grows in the community because local wisdom is formed as a process of interaction between individuals and their environment in order to meet their various needs. Even though it is said to be local, the wisdom actually contains universal moral values. For example, a village community whose life is simple, independent, not excessive, tolerant, wise in managing their finance, protective of the environment, and so on. This form of local wisdom provides opportunities for creativity in the community which in turn creates creative industries.

Creative industry can be defined as a collection of economic activities related to the creation or the use of knowledge and information. It is also known as cultural industry or creative economy (Hesmondhalgh and David, 2002). The Indonesian Ministry of Trade stated that creative industry is an industry that comes from the use of individual creativity, skills and talents to create prosperity and employment by generating and exploiting the creative power and creativity of these individuals. It is proven that creative industry has a significant role in the development of Indonesian national GDP. In 2017, creative industry was able to contribute around IDR 952 trillion or $7.28 \%$ of the total National GDP. The creative economy industry grew $4.95 \%$ in 2017 . This number showed an increase when compared to that of 2016 which was only $4.41 \%$. The largest contribution came from the culinary sector, which was as many as $41 \%$, followed by fashion industry $(17 \%)$, and crafts $(14.9 \%)$. In term of tourism, which is an inseparable part of the creative economy, creative economy actors must create their own appeal.

Creative economy is growing rapidly in Indonesia, including in Batu. In addition, the emergence of various thematic tours encourages the growth of creative economy in its society. All levels of society and government work together to create distinctiveness and introduce their respective regions, since Batu Tourism City is one of the largest tourist cities in Indonesia, where every year or every holiday period, many tourists come to this city. Therefore, it is not surprising that many new attractions are offered in this city. In addition, the culinary sub-sector and craft (batik) are among the leading economies in Batu that can attract tourists' interest (Sopanah, Bahri, Ghozali, 2019).

\section{Methodology}

In this study the research team used a qualitative analysis approach. The method used in this research is the Analytic Network Process (ANP), which is an analytical development of the Analytical Hierarchy Process (AHP) method. ANP allows for the interaction and feedback relationships among elements within the cluster (inner dependence) and among clusters (outer 
dependence). ANP is used for decision making that is very complex and requires a variety of interactions and dependencies among existing elements and clusters. As a development of the AHP method, ANP uses Pairwise Comparison Judgment Matrices (PCJM) between similar elements. ANP pairwise comparisons are carried out between elements in components or clusters for each interaction in the network (Rusydiana, 2013).

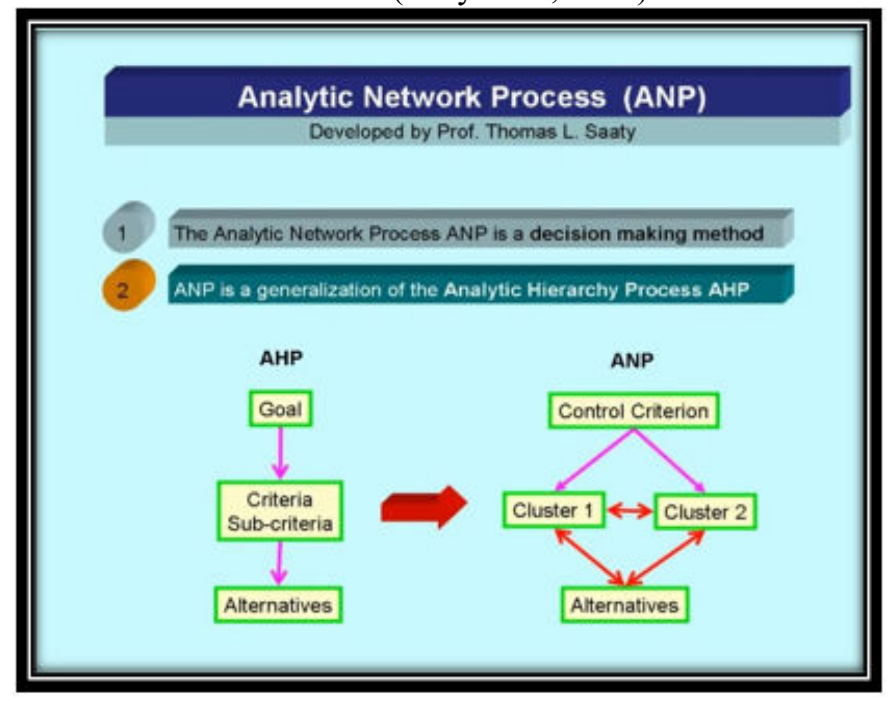

Fig 1. Analytic Network Process (ANP) Analysis

Respondents of this research are creative economy industry actors based on local wisdom (in the form of batik) in Batu. It is hoped that this methodical approach can produce the most influential impact and an important role in increasing community empowerment with the emergence of creative economy in the local environment.

\section{Results and Discussion}

Batik industry has the potential for excellence by carrying out the big theme of local wisdom which has urgency as the source of distinct and unique ideas. The diversity of batik patterns and characters is a big asset and profit source for batik craftsmen. The important point in the development of batik is the market trends or demands. Market trends change too quickly and are temporary. On the other hand, the superior potential and local wisdom are long term in nature. To maintain its existence, batik industry continues to make innovations both in terms of patterns and the coloring schemes. Keyes (2004: 81-93) stated that people are beginning to understand about quality and exclusive products so that having a one-of-a-kind object will increase their prestige of status, especially in the nowadays' era of social media and modern market.

From the researchers' observations, the following is a model of batik development strategy that can be developed by creative economy actors who have elements of local wisdom, especially batik. 
a. Model of Batik Development as an Industry From the perspective of Entrepreneur

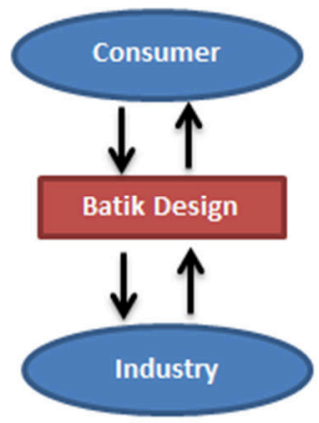

b. Model of Batik Development as a Craft From the perspective of cultural practitioner

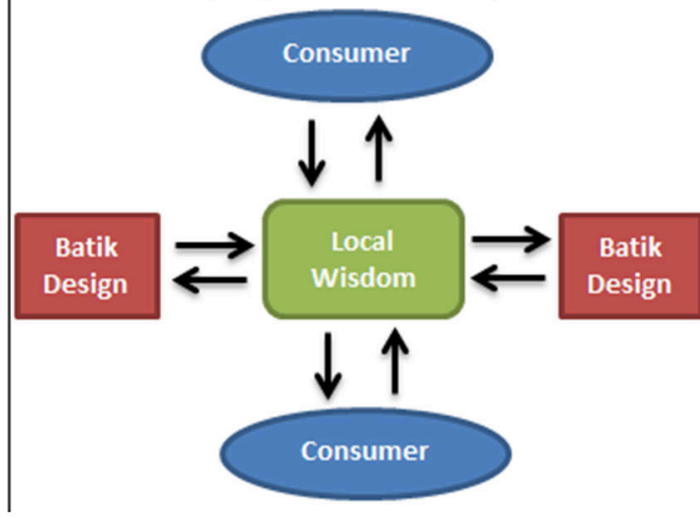

Fig 2. Correlation of Batik Development Model from Perspective of Entrepreneur and Cultural Practitioner

Figure A explains the batik development model from the entrepreneur's perspective, which is that the batik design is largely influenced by existing market trends and global color trends. This process is often used by batik entrepreneurs as a business opportunity to gain a place in the hearts of consumers and is expected to increase the demand for products in the market. They combine unique batik patterns and a bolder contrast in coloring.

Whereas, figure B describes the batik development model from the perspective of cultural practitioners who are oriented towards education. This batik is made solely to maintain and preserve the local wisdom of each region. The batik designs developed are based on the featured potential of local wisdom with its own characteristics. This batik pattern is made by bringing out regional characters so that it further clarifies Indonesian culture. Based on the results of researchers' observations and analyses, a community empowerment strategy can be formulated in the batik creative industry in Batu City. The strategies comprise of:

a. Strengthening community capacity which aims to foster community participation and increase interaction with a wider marketing network

b. Creating synergy between the government, batik creative economy actors and academics in formulating community empowerment programs and activities to be right on target and sustainable

c. Developing standardized batik products which in turn can increase the number of sales so that it can absorb more workers to meet market demand

d. Motivating the batik creative economy actors to be able to organize and carry out business development to increase income and access to marketing

\section{Conclusion}

Based on the survey results and FGD (Forum Group Discussion), it can be concluded that batik can be used as a promising business opportunity as well as a platform of cultural learning and preservation with the creation of a pattern based on local wisdom. The new pattern should definitely follow the global color trend in order to survive while maintaining the value of local wisdom poured into a sheet of cloth, which in the end creates a unique and elegant Indonesian batik. The added value from batik itself will be able to compete in the 
global market. The growth of the creative economy in the midst of society will have a profound impact on people's lives, especially in terms of their economy.

\section{Thank-You Note}

A big thank you to all parties who cannot be mentioned one by one, especially to the DPRM Dikti who has funded this research, the creative economy actors of Batu, Batu City Government and Widyagama University who always support the implementation of this research.

\section{Reference}

[1] Ministry of Trade of the Republic of Indonesia, 2008. Towards the Vision of Indonesia's Creative Economy, Ministry of Trade of the Republic of Indonesia, Jakarta.

[2] Hesmondhalgh, David (2002) The Cultural Industries, SAGE

[3] Nasir, \& Yuslinaini. (2017). Mapping Analysis of the Creative Industry in the Craft Subsector and the Impact of Improving Community Welfare in Aceh Besar District. Journal of Economics and Technology Management (EMT), 11-17.

[4] Nikolić, M., Filipović, M., \& Pokrajac, S. (2016). Regional Competitiveness for Achieving Sustainable Development - The Case of Serbia. Industrija , 7-26, Vol. 44, No.3.

[5] Permana, et al. (2014). Community Empowerment Strategies through Creative Economy Innovations in Poverty Reduction. Discourse, Vol. 17 No.4

[6] Soekarti, 1995. Agricultural Development, PT Raja Grafindo Persada, Jakarta.

[7] Sopanah, 2009, UMKM Empowerment Model in Malang Raya, PHB, DIKTI

[8] Sopanah, 2013, Community Empowerment Model through Access to Capital, Stanas, DIKTI

[9] Sopanah, 2016, Master Plan for Creative Economy Development in Malang City, Bappeda Malang City

[10] Sopanah, Syamsul Bahri, M Ghozali, 2018, Creative Economy Based on Local Wisdom as Efforts to Increase Global Competitiveness, 2018-2020 Higher Education Research and Technology Grants

[11] Sumartik. (2016). The activity of the Creative Economy to Increase UMKM Branding. Proceedings of the INDOCOMPAC National Seminar, 344-349.

[12] Tsertseil, JS, Kookueva, VV, Gryzunova, NV, \& Khaschuluun, C. (2017). Analysis and Prospects of Infrastructure Development of Innovation Regional Clusters in Russia through the Example of Specific Economic Zones of Industrial Production and Technology Innovation Types. Journal of Applied Economic Sciences, 1896-1905, Volume XII.

[13] Tiezzi , E ., Marchettini, T., and Rossini , M . TT. 1995. Extending the Environmental Wisdom beyond the Local Scenario: Ecodynamic Analysis and the Learning Community. In Ridwan, Nurma Ali, 2007. Scientific Foundation of Local Wisdom, Journal of Islamic and Cultural Studies, P3M STAIN Purwokerto, Ibda, Vol. 5, No. 1, Jan-Jun 2007, 27-38

[14] Law of the Republic of Indonesia Number 10 of 2009 concerning tourism 
[15] Wroblewsci, Ł. (2014). The Influence of Creative Industries on the Socio-Economic Development of Regions in Poland. International Journal of Entrepreneurial Knowledge, 45-67, Volume Utami, Ni Gusti Made, 2014, Creative Industry Development in Bandung City Through Tourism Clusters, Barista, Volume 1, No. 2, December 2014, 